ÇOMÜ Uluslararası Sosyal Bilimler Dergisi 3 (2), 293-315 , 2018

COMU International Journal of Social Sciences 3 (2), 293-315, 2018

\title{
Gastronomi Turizmi Çerçevesinde Çerkez Mutfağının İncelenmesi ${ }^{*}$
}

\author{
Rabia ÍLHAN ${ }^{* *}$ \\ Muammer MESCÍ $* * *$
}

Öz

$\mathrm{Bu}$ araştırmada, Çerkez mutfağının gastronomi turizmindeki yeri incelenmiştir. Bu bağlamda nitel araştırma yöntemlerinden, betimsel araştırma desenlerinden görüşme deseni kullanılmıştır. Araştırma kapsamında hazırlanan görüşme formunda 7 genel bilgiler ve 10 mülakat sorusu yer almaktadır. Farklı şehirde 12 farklı restoran sahibi ile yüz yüze görüşme yapılmıştır. Elde edilen verilere göre, katılımcılar Çerkez mutfağının gastronomi turizmine etki ettiğini dile getirmişler ve turizme katkının ise çoğunlukla yerli turist tarafından olduğu aktarılmıştır. Turistlerin Çerkez yemeklerine karşı tutumlarının ise olumlu olduğunu, lezzetlerin beğenildiği belirtilmiştir. Katılımcılar genelde Çerkez yemeklerinin yerli turistin damak tadına hitap ettiğini, damak tatlarının benzer olduğunu aktarmışlardır.

En çok tercih edilen çerkez yemeklerinin, Haluj, Abista, Abaza peyniri, Velibah, Aktisizbal, Ahulçapa ve Açaç olduğu sonucuna ulaşılmıştır. Turistlerin en çok tercih ettiği Çerkez yemeği ise Halujdur. Gastroturistlerin genellikle yemek tercihlerini restoranlara bıraktığı sonucuna ulaşılmıştır. Katılımcıların büyük çoğunluğu yöresel ürün kullandıklarını dile getirmişlerdir. Gastroturistlerin portföydeki yerleri ve turist artırma konusunda özel bir çalışma yapan restoranın neredeyse olmadığ 1 sonucuna ulaşılmıştır.

Anahtar Kelimeler: Gastronomi, Gastro Turist, Çerkez, Çerkez Mutfăğ.

\footnotetext{
* Bu çalışma Düzce Üniversitesi, Sosyal Bilimler Enstitüsü, Turizm ve Otel İşletmeciliği Anabilim Dalı bünyesinde ve Doç. Dr. Muammer Mesci danışmanlığında Rabia İLHAN tarafından hazırlanan ve 2018 yılında kabul edilen “Çerkez Mutfağının Gastronomi Turizmi Bağlamında Değerlendirilmesi: Restoran Sahipleri Ve Müşteri Görüşlerinin Karşılaştırmalı Analizi” başlıklı Yüksek Lisans Tezinden görüşme ile elde edilen veriler kullanılarak türetilmiştir.

(C) Sorumlu Yazar / Correnponding Author

** Bilim Uzmanı, Düzce Üniversitesi, Sosyal Bilimler Enstitüsü, rabiailhan06@windowslive.com

*** Doç. Dr., Düzce Üniversitesi, Akçakoca Turizm İşletmeciliği ve Otelcilik Yüksekokulu, muammermesci@ duzce.edu.tr
} 


\title{
Investigation of Circassian Cuisine in the Gastronomy Tourism Context
}

\begin{abstract}
In this research, the place of Circassian cuisine in gastronomy tourism has been investigated. In this context, interview design is used from qualitative research methods, descriptive research designs. In the interview form prepared within the scope of the research, 7 general information and 10 interview questions are included. Face-to-face interviews were held with 12 different restaurant owners in different cities. According to the obtained data, the participants stated that the Circassian cuisine influenced the gastronomic tourism and it was reported that the contribution of tourism was mainly by native tourists. It is stated that the attitudes of the tourists towards the Circassian food are positive and the tastes are appreciated. Participants generally conveyed that the Circassian cuisine addressed the tastes of indigenous tourists and that their palate tastes were similar.

Most preferred Circassian dishes are Haluj, Abista, Abaza cheese, Velibah, Aktisizbal, Ahulçapa and Açaç. Circassian food, which is most popular with tourists, is Haluj. Gastrotourists have often reached the point of leaving their choice of food to restaurants. The vast majority of participants expressed that they use local products. It has been found that there is almost no restaurants who does special study on the place of gastroturists on the portfolio and increasing the number of tourists.
\end{abstract}

Keywords: Gastronomy, Gastrotourist, Circassian, Circassian cuisine.

\section{GİRIS}

Dünya Turizm Örgütü’nün yapmış olduğu açıllamada turizm; "gidilen bölgede gelir elde etmeksizin ve bahsi geçen bölgeye yerleşmek amacı olmadan bireylerin yabancı ülkelere yaptıkları ziyaretler” şeklinde tanımlanmıştır (UNWTO, 1995).

Gastronomi ise, içinde bulundurduğu bütün sanatsal ve bilimsel ögelerle birlikte yiyecek ve içeceklerin tarihi gelişim sürecinden başlayarak her bir özelliğinin ayrıntılı bir biçimde anlaşılmasını, uygulanmasını ve geliştirilerek günümüz koşullarına uyarlanmasını hedefleyen çalışmaları içeren bir bilim dalıdır, şeklinde tanımlanabilir (Eren, 2007:74). Gastronomi, özetle ve kısaca; sağlığa uygun, iyi düzenlenmiş, hoş ve lezzetli mutfak, yemek düzeni ve sistemi demek olmaktadır. Başka bir tanıma göre ise gastronomi; yeme - içme bilimi ve sanatı demektir. Bu bilgi, bir disiplin olarak, kültürle yemek arasındaki ilişkiyi inceleyen bir çalışma alanı olmaktadır (Ünlü ve Dönmez, 2008:2). 
Gastronomi dünyadaki birçok önemli ülkesinin ulusal yemek ve içecek kültürlerinin en ayrıntılı biçimde bilinmesini gerektirir. Sonuçta gastronomi de yiyecek ve içeceklerle ilgili malzemelerin nasıl kullanılacağının anlaşılmasını gerçekleştiren bir platform olarak karşımıza çıkmaktadır. Bu yolla yiyecek ve içecekler açısından farklı kültür ve ülkelerin yaklaşımlarındaki benzerlikleri ve farklılıkları bir bütün olarak görmek ve öğrenmek imkanı sağlayabilmektedir (Hatipoğlu, 2010: 5).

“Çerkez" kelimesi etnik köken ayrımı göz önünde bulundurulmaksızın 17. yüzyıldan bu yana Karaçay, Balkar, Dağıstan, Adıge ve Abhaz olsun Kafkasyada yaşayan Müslümanların tamamına verilen isim olarak kabul görmekteydi (Kaya, 2011:99). Bunun yanında Çerkezlerin Kafkasyàda yaşadıkları bölgelerin genel adı bazı kaynaklarda "Çerkezistan" olarak yer almaktadır (Cevdet Paşa, 1993: 243-248).

Bu araştırmanın amacı, Çerkez mutfağının gastronomi turizmindeki yerinin incelenmesi, gastronomi turizmine olan katkılarının bulunmasıdır. $\mathrm{Bu}$ makale, nitel araştırma yöntemlerinden, görüşme deseni ile yapılmıştır. Farklı illerde yer alan 12 farklı restoran ile görüşme yapılmış ve sonuçlar yorumlanmıştır.

$\mathrm{Bu}$ araştırma neticesinde elde edilen bilgilerden yola çıkılarak Çerkez mutfağının gastronomi turizminde yeri belirlenebilecektir. Bu bağlamda gastroturist çekmek adına çeşitli önerilerde bulunabilecek ve bu sayede bölge gastronomi turizmine geliştirici etkide bulunulabilecektir.

\section{GASTRONOMI TURIZMI}

Gastronomi turizmini, Long (2003:21), "Değişik bir mutfak kültürü içinde yer alan yiyeceklerin hazırlanması, sunulması, tüketilmesi; mutfağı, öğün sistemlerini, yeme tarzlarını tespit etmek amacıyla gerçekleştirilen turizm türü” diye tanımlamıştır.

Turizm kendi ekseninde giderek gelişen bir sektördür; ancak bu bağlamda, yiyecekiçecek sektörü de turistlerin farklı tatil seçenek ve davranışları üstünde belirleyici rol oynamaktadır. Öyle ki, o, yeni yerleri ziyaret, bilinmeyen bölgesel lezzetleri deneme ve ilave olarak da yeni kültürleri, gelenekleri tanıma, anlama ve takdir etme bağlamında çeşitli imkanları turistlere sunar. Gastronomi turizmi açısından, yalnızca seyahatlerinin zorunlu anları olarak yiyecek tüketen turistlerle davranış, tutum ve ziyaret edilecek bölge tercihlerini, gidilmek istenen bölgedeki yiyeceklere göre belirleyen turistleri birbirinden ayırmak gerekir (Cook, Yale ve Marqua, 2000:127).

Gastronomi turizmi, hazırlanan yiyecek ve içeceklerin ilgi uyandıracak biçimde turistlere sunulmasıdır. Bu konuda geçerli olabilecek lezzetlerin bir gazeteci tarafından önerilmiş olması gerekmemektedir. Gastroturist kibir taşımayan araştırmacı bir kişilik olmalıdır. Tüketim denilen olgu, turizmin ayrılmaz bir parçasıdır ve bu anlamda turist de görüntü ve seslerin yanında, aynı şekilde bir bölgenin tatlarını da tüketir. Yemek başka bir kültür ile bütünleşmek için çok değerli bir adımdır. Yemek, kişilere "diğerleri”ni aklıyla 
olduğu kadar, bunun yanında duyularıyla da tanıma imkânı verir. Bu şekilde de bölgesel yiyecekler, bir turizm bölgesine ilişkin olan özelliklerin en önemli noktasını oluştururlar (Demir, 2011: 51).

\subsection{Gastro Turist Tanımı}

Mutfak turizmi ve yiyecek turizmi gibi kavramlar gastronomi turizmi ile ilgili kaynaklarda yer almakta olup, bahsi geçen kavramlar genel olarak birbirlerinin yerine kullanılmalarına karşın talep düzleminde niteliksel ve niceliksel olarak birbirlerinden farklı niteliktedirler, aynı zamanda söz konusu kavramlar öznesini yiyecek tüketimine yönelik turizm hareketlerinin oluşturduğu kavramlar olmaları ile de birbirleri ile etkileşim halindedirler. Nadir bulunan yiyecekleri sosyal bir aktivite olarak yeni şeyler bulmak maksadı ile farklı ülkeleri ziyaret eden bu gruplar, "gastro turist” kavramının da doğmasını sağlamışlardır (Hatipoğlu, 2010: 4). Gastro turist yalnızca yeme ihtiyacını karşılamak için değil, bunun yanında farklılık yaşamak için yemek kültüründe farklılıklar oluşturan deneyimleri tecrübe edinen turist olarak tanımlanmaktadır (Long, 2003: 21).

\subsection{Turistik Deneyim Olarak Gastronomi}

Turistik deneyim olgusunun, genellikle, turistin kendini destinasyonda hissetmesiyle (mekân algisı), çekim ögelerini ziyaret etmesiyle, toplam turistik ürünü tüketmiş olmasıyla ve bütün bunların sonunda ortaya çıkan bilişsel sürecin sonunda meydana gelmektedir (Kurgun ve Özşeker, 2016: 733).

Yeme-içme etkinliği, deneyim oluşturma hususunda belirgin bir üstünlüğe sahiptir. Öncelikle, beslenme konusu kişilere mutluluk verir. Tat alma denilen olgu, doğrudan doğruya kokuyla başlar. Çevreden gelen kokular insan beyninde bulunan yaklaşık 350 koku alıcısı üzerinde uyarıcı etkide bulunmakta olup, söz konusu alıcılar ortaklaşa hareket ederek beyinde besinin koku profilini çıkarırlar. Daha sonraki aşamada besin çiğnenip oksijenle temasa geçtiğinde burun arkası (retronazal) alıcılar damağın arkasından daha çeşitli ve daha şiddetli koku sinyalleri göndermektedir. Sonra da dilin yüzeyindeki binlerce tat alma kabarcı̆̆ı (papilla) ve her birinde yer alan 50-100 tat alıcısı beş ana tat konusunda beyne sinyaller göndermektedir. Beyne giden bütün bu sinyaller, besinden alınan hazzın derecesini belirleyecektir (Baral, 2015).

Fazladan olarak duyulara seslenen yeme-içme etkinliğinde de tüketilen incelikli, farklı ve lezzetli ürünler, olumlu duygulara, kalıcı ve hatırlanabilir deneyimlere vesile olur. Mekân algısını meydana getiren, turistin destinasyonu hissetmesini sağlayan somut ve soyut ögeler, kişilerin duyuları aracılığıyla algılanır. Bu gerçeklerden hareketle, mekân algısını oluşturan ögelerden yerel yiyecek-içecekler, tatma ve koku duyularına hitap ederek, derin ve çok güçlü anılar yapabilirler (Kurgun ve Özşeker, 2016: 34). 


\subsection{Yöresel Tatların Destinasyon Tercihine Olan Etkisi}

Bir bölgeyi eşsiz kılan en önemli cazibelerden biri şeklinde nitelendirilen yöresel mutfaklar bölgenin soyut mirasının bir yansıması olarak görülmekte ve söz konusu ürün tüketimini gerçekleştiren turistlere otantik kültürel bir deneyim yaşatmaktadırlar (Örn. Çin, İtalyan, Türk Mutfağı) (Hacıŏlu vd., 2009).

Birleşmiş Milletler (BM) Dünya Seyahat Örgütü verileri doğrultusunda, dünya çapından gerçekleştirilen turizm gelirleri içerisinde yeme-içme harcamalarının payı \%30 olarak belirlenmiştir. Turistlerin yüzde 88.2'si bölgenin sahip olduğu yemek kültürü için "seyahat için gidilecek yer seçimimde yemek çok önemli" derken sadece yüzde 11.8 gibi küçük bir kesim "yemek, bölge seçimlerimde küçük bir role sahip" cevabını vermektedir (Tezcan, 2000: 8). Bir bölgenin turistik bölge olma profilini geliştirme ya da kötüleştirme hususunda güçlü ve etkili bir yere sahip olan yemek unsuru içerisinde, özgün coğrafi kökene sahip yemekler, bölge imajını çekici hale getirerek, markalaşmayı ve kırsal turizmin güçlendirilmesini sağlar. Söz konusu durum özellikle yemek, şarap ve turizm meraklıları açısından büyük önem taşımaktadır (Green ve Dougherty, 2008: 150).

Bir bölgede yemek ve şarap potansiyelinin varlığı, yöresel ve kırsal kalkınmaya katkı sağlamanın yanı sıra yeni iş alanlarının oluşturulmasında, bunun yanı sıra yeme, içme ve konaklama işletmelerinin faaliyete girmesinde etkili olabilecektir. Gastronomi turizmi, kırsal toplumlar için, turizm ile şahsi yerel yiyecek ve içeceklerinin bütünleştirmede alternatif olanaklar sunmaktadır. Söz konusu süreç bölgesel kalkınmanın yanı sıra, bölgenin kültür mirasının korunarak geliştirilmesine de katkı sağlamaktadır (Çağl1, 2012: 30).

Yöresel mutfak deneyimini tüm yönleriyle turizm destinasyon deneyimiyle bütünleştirmenin en iyi yollarından bir tanesi de yöresel yiyecek ve içeceklerin destinasyonda bulunan otellerin ve restoranların menülerinde yer alması ve bununla birlikte bu kapsamda gastronomi ile ilgili faaliyetler düzenleyip, destinasyona gelen turistlerin ilgilerini çekerek bölgeye ait yöresel yemekleri ve içecekleri tatma imkânı sağlamaktır (Bucak ve Arac1, 2013: 208).

Yiyecekler ve yemekler, sosyo-kültürel anlamı ve değeri olan kültürün vazgeçilmez ögelerinden olması yönüyle bir kültürün maddi ögesi ve her kültürde görülen temel bir öge konumundadır. Bunun yanı sıra ulusların sahip oldukları özgün beslenme tür ve kültürleri onların medeniyet seviyelerine 1 şı tutan bir fener görevi görmekte olup kültürlerin beslenme medeniyet şekillerinin farklılık göstermesi, besin ve beslenme tiplerinin farklılaşmasına olanak tanımıştır. Bunun yanı sıra coğrafi koşulların insanlara sağlamış olduğu kültürel yapı, sosyo-ekonomik düzey ile eğitim-öğrenim durumu da söz konusu farklılaşmanın oluşumunda etkin bir rol oynamaktadır (Hacıoğlu ve Avcıkurt, 2011: 434). 


\subsection{Türkiye'de Gastronomi Turizmi}

Türk mutfağının gelişim süreci araştırıldığında görülecektir ki Türkler, Anadolu’ya yerleşmeleriyle birlikte Anadolu mutfağını ve özelliklerini benimsemişlerdir. Orta Asya'dan taşıdıkları mutfak kültürlerini yeni yerleşim bölgesindeki mutfak kültürüyle sentezleyerek daha zenginleştirmişlerdir. İlerleyen dönemler ise, Osmanlı İmparatorluğu'nun coğrafi genişlemesiyle uyumlu biçimde, farklı coğrafi ve kültürel bölgelere ait çok çeşitli gastronomik zenginlikler Türk mutfağı bünyesine dahil edilmiş olup, Türk mutfağ1 böylece süreç içinde "füzyon mutfağı" niteliği edinmiş durumdadır. Bu sebeple Türk mutfağı bugün için bilinen en eski ve en zengin mutfaklardan biri olmaktadır (Akgöl, 2012; Bilgin ve Samanc1, 2008).

TÜRSAB’’n Gastronomi Turizmi Raporu (2015)'na göre ülkemizde turizm gelirleri içinde en büyük pay yiyecek içecek bölümüne aittir. Konaklama gelirlerinden de önce gelen ve böylelikle ilk sıraya yerleşen yiyecek içecek harcamalarının toplam gelir içindeki payı \% 20 ile 25 arası bir oranı ifade etmektedir. Ülkemizde turist başına harcama ortalama olarak 828 dolardır; bunun 157 doları ise yeme -içme için harcanmaktadır. Yurt içi ve yurt dişı ekseninde tanıtım yapabilme adına coğrafi işaretle tescillenmiş durumdaki ürünler, bir başka söylemle belirtilirse, belirli bir yöreye özgü olduğu kamu kurumları tarafından onaylanmış durumdaki ürünler çok önemli ve çok değerli turizm değerleri ve ögeleri olmaktadırlar. Türkiye'nin zengin mutfağından şu an için tescillenmiş durumdaki ürün sayısı henüz çok azdır. Türk Patent Enstitüsü’nden coğrafi işaret belgesi almış bulunan gıda sayısı ise yalnızca 124'tür. Türk Patent Enstitüsü’nden coğrafi işaret almak üzere başvurusu yapılmış ve bu başvurusunun sonuçlanmasını bekleyen gıda ürünü sayısı ise 185 tir. Bu konuda bir fikir vermesi açısından şu örneği vermek yerinde olacaktır: En çok tescil bekleyen illerimizden olan Şanlıurfa 26 yemeğinin coğrafi işaretle tescillenmesi için sıradadır. Söz konusu Şanlıurfa yemekleri arasında, Urfa ciğer kebabı, Miftahi tas kebabı, Urfa pancar boranası, Urfa eşkilisi, Urfa soğan kebabı gibi ürünler vardır. Gastronomi, kültürel değerler bakımından da çok büyük bir değer ve öneme sahip bulunmaktadır. UNESCO’nun İnsanlığın Somut Olmayan Kültürel Mirası Listesi bu anlamda önemlidir. Bu bağlamda Türkiye’nin yaptığı başvurular çerçevesinde 28 Kasım 2011'de Geleneksel Tören Keşkeği, 6 Aralık 2012'de Mesir Macunu Festivali, 2013 yılında da Türk Kahvesi ve Geleneği bu listeye dahil edilmiştir (TURSAB, 2015). Alternatif bir turizm anlayış1 olduğundan ve giderek de daha çok ilgi gösterilen ve kişilere ve toplumlara daha çok kazandıran bir turizm türü olduğundan gastronomi turizmi için Türk turizmcileri de harekete geçmiş bulunmaktadır.

Şanlıer (2005)'in gerçekleştirdiği araştırmada Türk mutfağının tanıtımında bir dizi yanlışın olduğu ve bu alamda en başta da turistlere kendi kültürlerine ait yemeklerin sunulduğu saptanmış bulunmaktadır.

Birdir ve Akgöl (2015) turistlerin, ülkemiz mutfağına dair bilgileri yemekleri deneyen kimselerin tavsiye etmeleriyle kazandıklarını saptamıştır. Ayrıca bu çalışmayla, turistlerin tekrar gelme arzu ve düşüncelerinin oluşmasında Türk mutfağına has yiyecek ve içecekleri 
yeniden tatma gibi olguların ancak 3. sırada olabildiği saptanmıştır.

Gökdeniz ve diğerleri (2015) de yürüttükleri çalışmada, turistlerin bölgeye geliş nedenleri içinde Ayvalık mutfağının ancak dördüncü sırada yer aldığını ve bu konuda kararsız kaldıklarını saptamışlardır.

Antalya’da Yiyecek İçecek Yöneticileri Derneği (YİYDER) ve Akdeniz Üniversitesi Alanya İşletme Fakültesi'nin yürüttükleri ortak çalışmayla üç kez düzenlenen 1., 2. ve 3. Ulusal Gastronomi Sempozyumları yoluyla gastronomi bilinci ve kavramın, Türk Turizmi için ifade ettiği anlam ve önemi, sektör personelleri ve akademisyenler tarafından sunulan bildirilerle ifade edilmiş ve böylece yemek-mutfak kültürünün gelişimine katkı verecek yeni fikirlerin her yıl panellerde yer bulmasına vesile olunmaya çalışılmıştır. Bu şekildeki çalışmalarla mutfak ve yemek kültürüne yüklenen değer, turizmciler tarafından sektör çalışanlarına ve sektöre ilgi duyan insanlara aktarılmaya çabalanmaktadır (Dilsiz, 2010: 21).

Turizm Yazarları ve Gazetecileri Derneği (TUYED) marifetiyle düzenlenmiş bulunan panelde, "Yabancı zincir otellerin ülkemize girişi realitesiyle birlikte, aynı zamanda ülkemiz gastronomisinde önemli bir noktaya da gelindiği ve anılan bu yeni gelişmenin de yabancı şef aşçıları ülkemize çektiği” saptanmış bulunmaktadır. Söz konusu bu gelişimin, aynı anda yeni bir Türk aşçı kuşağının yetiştirilmesi gibi olması gereken doğrultuda olumlu bir olguya da yol açtı̆̆ 1 saptanmıştır. Bütün bunlara ilave olarak panelde, fuar aktivitelerinin de Türk Mutfağı ve aşçılığının kişisel ürünlerini sergilemesi bakımından da çok değerli ve önemli bir tanıtım aracı olduğu gerçeğine vurgu yapılmıştır (www.tuyed.org.tr/).

Ülkemiz açısından Anadolu Gurme Turları yoluyla köylerde, söz konusu o köyün ünlüözgün-yerel yemeklerini yapacak kadınların belirlenmesi ve o kadınların evlerinin bir köşesini veya bahçesini küçük bir lokantaya çevrilebilmeleri için kendilerine küçük fakat yeterli kredilerin verilmesi özellikle tavsiye edilmektedir. Ayrıca, gelen turistlerin söz konusu lokantalara yönlendirilmesi yoluyla da bu girişimler sonucunda aile ekonomilerine de hatırı sayılır seviyelerde katkı sağlanmış olacağı ve giderek de ülke ve bölge yemeklerinin sürekli tanınır duruma geçeceği özellikle vurgulanmaktadır (Güneş vd., 2008).

\section{5. Çerkez Mutfağı}

İçerik bakımından ele alındığında Çerkez, Çerkes, Adiğe, Kafkaslı, Kafkasyalı kavramları arasında fark olmadığı görülmektedir. Kafkas Dağları’nın eteklerinden yaşayan çeşitli etnik kökenli toplulukları ifade eden "Kafkasyalı" geniş kapsamlı bir kavram olarak kullanılırken; "Kafkaslı" ise Kafkas ırkına mensup olduğu düşünülen, söz konusu bölgenin yerel halkına verilen ve aidiyet duygusu barındıran bir sıfat niteliğindedir. Berkok eserinde "Kafkaslı" kavramını oldukça sık bir biçimde kullanmıştır. Writhte ise Kafkas kelimesinin aslı olan "Kas halkı" ismini ilk kullanan kişi olarak bilinmektedir (Yılmaz, 2017: 54). 
Günümüzde Astrahan eyaletinin güneyi ve Don'dan başlayarak Türk ve İran sınırlarına kadar uzanan toprakları içine alan Kafkasya sınırları içerisinde çoğu Kafkas halkı hayatını sürdürmektedir. Söz konusu coğrafyada yaşayan Adigeler ve diğer kabilelerin tümü “Çerkez” olarak bilinmektedir (Akt. Kurgun ve Özşeker, 2016: 733).

Ortak özelliklere sahip olan Adığe, Abhas, Çeçen, İnguş, Oset, Karaçay, Balkar, Dağıstan mutfaklarının birleşiminden oluşan Çerkez mutfağında genel olarak et ve süt ürünlerinin ağırlıklı olduğu görülmektedir. Haşlanmış, kurutulmuş, fırında pişirilmiş et ürünleri Çerkeslerin sevdiği ve tercih ettiği ürünlerdendir. Söz konusu bölgelerde genel olarak aynı yemek kendi dilleri ile farklı isimlerle ifade edilmektedir. Örnek vermek gerekirse Adiğeler'deki Şipsi, Abhaslarda "Acıka”, Karaçaylar'da "Hıcın”, Azerilerde "Kavurma” gibi isimlerle ifade edilen yemek genel olarak aynı yemektir. Çerkeş’lerde, 12 Çeşit Şipsi, 12 Çeşit Libje, 12 Çeşit Çerkeş Tavuğu bulunmaktadır. Çerkeş aşüresi en az 12 çeşit malzemeden yapılmakta olup, Çerkeş tuzuna en az 12 çeşit baharat katılmaktadır (Yılmaz, 2017: 545).

\section{YÖNTEM}

$\mathrm{Bu}$ çalışma nitel araştırma yöntemi ile oluşturulup, betimsel araştırma desenlerinden görüşme deseni kullanılmıştır. Stewart ve Cash (1985) görüşme tekniğini “önceden belirlenmiş ve ciddi bir amaç için yapılan, soru sorma ve yanıtlama tarzına dayalı karşılıklı ve etkileşimli bir iletişim süreci” şeklinde ifade etmişlerdir (Akt. Yıldırım ve Şimşek, 2016). Bu araştırmanın evrenini Sakarya, Kayseri, İstanbul, Düzce, Antalya, Ankara illerinde yer alan Çerkez restoranları oluşturmaktadır. Bu illerde yer alan 12 farklı restoran araştırmaya dahil olmuştur.

\subsection{Veri Toplama Araçları}

Araştırma kapsamında araştırmacı tarafından hazırlanan görüşme formunda 7 genel bilgiler ve 10 mülakat sorusu yer almaktadır. Toplamda 12 restoran sahibi ile mülakat gerçekleştirilmiştir.

\subsection{Verilerin Toplanması ve Analizi}

Görüşme formu için sorular hazırlanırken, yazdığımız ilgili lüteratür ve daha önceden yapılmış benzer araştırmalar ve bu araştırmaların sonuçlarından yararlanılmıştır. Hazırlanan sorular uzman akademisyenler tarafından kontrol edilmiş ve onay alındıktan sonra ilgili kişilere uygulanmıştır.

$\mathrm{Bu}$ araştırmada Çerkez yemekleri yapan restoran sahipleri ile görüşme yapılmıştır. Çerkez restoranlarının bulunduğu iller belirlenerek, bu illerde görüşmeyi kabul eden çerkez restoranlarının tamamı ile görüşülmüş, veri toplama da uygun ve yeterli katılım sağlanmaya çalışılmıştır. Önceden hazırlamış olan görüşme soruları restoran sahiplerine yüzyüze mülakat halinde sorulmuştur. 
Görüşmeler her katılımcı ile yüz yüze ve bire bir yapılmış, verilerin kaydedilmesi ise ses kayıt cihazı kullanılarak gerçekleştirilmiştir. Görüşülen katılımcıların tamamı ses kayıt cihazının kullanılmasında bir sakınca olmadığını belirtmişler ve süreç içerisinde ses kaydından rahatsız olmadıkları da araştırmacı tarafından gözlemlenmiştir.

Bu araştırma nitel araştırma tekniklerinden görüşme tekniği ile yürütülmüştür. Bu sebeple görüşme tekniğinde verilerin analizi betimsel analiz ile yapılmıştır. Elde edilen veriler anlamlı bölümlere (sözcük, cümle vb.) ortak isimler verilerek kodlanmıștır.

\section{BULGULAR}

$\mathrm{Bu}$ bölümde araştırma sorularının analize dayalı olarak elde edilen bulgular yorumlanmıştır. Görüşmeler sonucu elde edilen genel bilgiler Tablo 1'de yer almaktadır.

Tablo 1: Genel Bilgiler

\begin{tabular}{|c|c|c|c|}
\hline & & $\mathrm{n}$ & $\%$ \\
\hline \multirow{3}{*}{ İşletme Türü } & Zincir İşletmeye Bağlı & 1 & 8,33 \\
\hline & Bağımsız & 11 & 91,67 \\
\hline & Diğger & & \\
\hline \multirow{4}{*}{ Hizmet Süresi } & $1-3$ yil & 2 & 16,66 \\
\hline & $4-6$ yll & 2 & 16,66 \\
\hline & $7-10$ yil & 4 & 33.34 \\
\hline & 11 yıl veya üstü & 4 & 33.34 \\
\hline \multirow{5}{*}{ En fazla tercih eden yaş grubu } & $15-25$ yaş & & \\
\hline & $26-35$ yaş & & \\
\hline & $36-45$ yaş & 10 & 83,34 \\
\hline & $46-55$ yaş & 2 & 16,66 \\
\hline & 56 yaş üstü & & \\
\hline \multirow{5}{*}{ Servis Şekli } & Ala Carte & 12 & 100 \\
\hline & Table D'Hote & & \\
\hline & Self Servis & & \\
\hline & Açık Büfe & & \\
\hline & Diğer & & \\
\hline \multirow{5}{*}{ Müşteri Kapasitesi } & 50'den az kişi & 3 & 25 \\
\hline & 51-100 kişi & 6 & 50 \\
\hline & 101-150 kişi & & \\
\hline & 151-200 kişi & 2 & 16,67 \\
\hline & 201' den fazla kişi & 1 & 8,33 \\
\hline \multirow{5}{*}{ Çerkez Mutfağı Denilince Akla İlk Gelen } & Kültür/Gelenek & 5 & 35,75 \\
\hline & Hamur İşleri & 4 & 28,57 \\
\hline & Mant1 & 3 & 21,43 \\
\hline & Çerkez Tavuğu & 1 & 7,14 \\
\hline & Patates & 1 & 7,14 \\
\hline
\end{tabular}


Tablo 1'de yer alan bilgilere göre, görüşme yapılan işletmelerin sadece 1'i zincir işletmeye bağlı iken diğerleri bağımsızdır. Hizmet sürelerine bakıldığında 4 işletme 7-10 yıl, 4 işletme 11 ve üstü yıldır hizmet verdiği saptanmıştır. İşletmelerin hepsi Ala carta servis şeklinde hizmet vermektedir. Müşteri kapasitelerine bakıldığında, 6 işletme 51-100 kişi, 3 işletme 50'den az kişi, 2 işletme 151-200kişi ve 1 işletme ise 201'den fazla kişiye aynı anda hizmet verebildiklerini söylemişlerdir.

İşletmelere Çerkez mutfağı denilince akla ilk gelen sorulmuştur. Alınan cevaplara göre Kültür/Gelenek 5 farklı işletmenin cevabı ile ilk sırada yer almıştır. Sonrasında hamur işleri ve mantı gelmektedir.

\subsection{Mülakat Soruları}

Bu bölümde mülakat sorularından elde edilen cevapların analizlerine yer verilecektir.

\subsection{1. Çerkez Yemekleri ve Gastronomi Turizmi}

Çalışma gurubundaki katılımcılara "Bölgenizde Çerkez yemekleri gastronomi turizmine etki etmekte midir? Etnik Çerkez yemekleri denemek için seyahat eden yerli ya da yabancı turistler bölgenizi ziyaret ediyorlar mı? Genel görüş nedir?” temel sorusu yöneltilmiştir. Katılımcıların verdiği cevaplara ilişkin özel ve önemli görülen kısımlar çalışma gurubunda yer alan kişilerin ifadeleri ile aşağıda özetlenmektedir.

\section{Tablo 2: Çerkez Yemekleri ve Gastronomi Turizmi}

\begin{tabular}{|c|c|c|c|}
\hline Kategoriler & Kodlar & $\mathrm{n}$ & Katılımcı \\
\hline $\begin{array}{l}\text { Bölgenizde Çerkez yemekleri gastronomi turizmine } \\
\text { etki etmekte midir? }\end{array}$ & Evet & 9 & $\begin{array}{l}\mathrm{K} 1, \mathrm{~K} 3, \mathrm{~K} 4, \mathrm{~K} 5, \mathrm{~K} 8 \\
\mathrm{~K} 9, \mathrm{~K} 10, \mathrm{~K} 11, \mathrm{~K} 12\end{array}$ \\
\hline \multirow{4}{*}{$\begin{array}{l}\text { Etnik Çerkez yemekleri denemek için seyahat eden } \\
\text { yerli ya da yabancı turistler bölgenizi ziyaret ediyor- } \\
\text { lar mı? }\end{array}$} & Yerli & 7 & $\begin{array}{l}\mathrm{K} 1, \mathrm{~K} 4, \mathrm{~K} 5, \mathrm{~K} 6, \mathrm{~K} 7, \\
\mathrm{~K} 8, \mathrm{~K} 12\end{array}$ \\
\hline & Yerli ve Yabancı & 3 & K4, K9, K11 \\
\hline & Ankara-İstanbul & 2 & $\mathrm{~K} 1, \mathrm{~K} 8$ \\
\hline & Civar İller & 2 & $\mathrm{~K} 2, \mathrm{~K} 5$ \\
\hline \multirow{11}{*}{ Genel görüş nedir? } & Organik yiyeceklere İlgi & 1 & $\mathrm{~K} 1$ \\
\hline & Sağlıklı & 2 & $\mathrm{~K} 2, \mathrm{~K} 6$, \\
\hline & Lezzetli & 3 & $\mathrm{~K} 2, \mathrm{~K} 6, \mathrm{~K} 12$ \\
\hline & Beğeni & 9 & $\begin{array}{l}\mathrm{K} 3, \mathrm{~K} 4, \mathrm{~K} 7, \mathrm{~K} 8, \mathrm{~K} 11 \text {, } \\
\mathrm{K} 9, \mathrm{~K} 10, \mathrm{~K} 12\end{array}$ \\
\hline & Memnuniyet & 3 & $\mathrm{~K} 3, \mathrm{~K} 4, \mathrm{~K} 12$ \\
\hline & Entereasan & 1 & K4 \\
\hline & Tanıdık & 2 & $\mathrm{~K} 4, \mathrm{~K} 12$ \\
\hline & Batı Halkı Beğeniyor & 1 & K5 \\
\hline & Doğu Halkı Beğenmiyor & 1 & K5 \\
\hline & Samimi & 2 & K6, K8 \\
\hline & Yoğun Tat & 1 & K9 \\
\hline
\end{tabular}


Tablo 2'de Çerkez yemekleri ve gastronomi turizmi ilişkisi incelenmiştir. Soru 3 kategori altında kodlanmıştır. İlk kodda Çerkez yemeklerinin gastronomi turizmine olan etkisi sorulmuş ve 9 katılımcı etki ettiğinden bahsetmiştir.

İkinci kodda, etnik Çerkez yemeklerini denemek için yerli ve yabancı turistlerin bölgeye gelip gelmedikleri sorulmuştur. Genel olarak (7 katılımcı) yerli turistlerin Çerkez yemekleri için bölgeye geldiklerinden bahsedilmiştir. 3 katılımcı ise hem yerli hem de yabancı turistlerin bölgelerine Çerkez yemekleri için geldiklerinden bahsetmiştir. K1 bu konuda "Bize yerli turist geliyor yabancı gelmez" şeklinde cevap vermiștir. K9 ise "Yerli ve yabancı turistler geliyor. Tavsiye üzerine gelen çok oluyor.” şeklinde bilgilerini aktarmıştır.

Üçüncü kodda ise turistlerin genel görüşleri sorulmuştur. 9 katılımcı Çerkez yemeklerinin beğenildiğini, 3 katılımcı lezzetli, 3 katılımcının ise memnun ayrıldıklarını aktarmıștır. K4 bu konudaki görüşlerini şu şekilde aktarmıştır; "Ya çok enteresan buluyorlar ya da çok tanıdık. Henüz hiç olumsuz yorumla karşılaşmadım, herkes çok memnun ayrılıyor”.

\subsection{2. Çerkez Yemekleri ve Turistlerin Damak Tatlarının İlişkisi}

Çalışma gurubundaki katılımcılara "Çerkez yemekleri ve genel turistlerin damak tatları arasında nasıl bir ilişki olduğunu düşünüyorsunuz?” temel sorusu yöneltilmiştir. Katılımcıların verdiği cevaplara ilişkin özel ve önemli görülen kısımlar çalışma gurubunda yer alan kişilerin ifadeleri ile aşağıda özetlenmektedir.

\section{Tablo 3: Çerkez Yemekleri ve Damak Tadı İlişkisi}

\begin{tabular}{lll}
\hline Kodlar & $\mathrm{n}$ & Katılımc1 \\
\hline Damak Tatları Benziyor & 12 & $\mathrm{~K} 1, \mathrm{~K} 2, \mathrm{~K} 3, \mathrm{~K} 4, \mathrm{~K} 5, \mathrm{~K} 6, \mathrm{~K} 7, \mathrm{~K} 8, \mathrm{~K} 9, \mathrm{~K} 10, \mathrm{~K} 11, \mathrm{~K} 12$ \\
Lezzetleri farklı & 5 & $\mathrm{~K} 3, \mathrm{~K} 5, \mathrm{~K} 8, \mathrm{~K} 10, \mathrm{~K} 12$ \\
Çerkez yemeklerinin tatları yoğun & 2 & $\mathrm{~K} 2, \mathrm{~K} 5$ \\
Tanıdık Geliyor & 1 & $\mathrm{~K} 1$ \\
\hline
\end{tabular}

Tablo 3'de Çerkez yemekleri ve turistlerin damak tatlarının ilişkisine ilişkin cevaplar yer almaktadır. Katılımcıların hepsi Çerkez yemekleri ile turistlerin damak tatlarının benzer olduğunu belirtmişlerdir. 5 katılımcı ise damak tatlarının benzer olmalarının yanında Çerkez yemeklerinde lezzet farkının olduğunu aktarmıştır. K11 bu konuda görüşünü şu şekilde dile getirmiştir; "Benzerlik gösteriyor. Özellikle hamur işi yiyecekler benziyor. En çok Karadenizyemekleri ile benzerlikgösteriyor”. K4 ise “Genel olarak benzediğini düşünüyorum. İtalyan, Rus, Uzak Doğu turistleri ile benzerlik gösteriyor” şeklinde görüşlerini belirtmiştir.

\subsubsection{Turistlerin Yemek Öncelikleri}

Çalışma gurubundaki katılımcılara "Bölgenize gelen turistlerin yemek önceliklerinin Çerkez yemekleri olduğunu düşünüyor musunuz? Diğer restoranlara göre bu bağlamda konumuzu nasıl görüyorsunuz?” temel sorusu yöneltilmiştir. Katılımcıların verdiği cevaplara ilişkin 
özel ve önemli görülen kısımlar çalışma gurubunda yer alan kişilerin ifadeleri ile aşağıda özetlenmektedir.

\section{Tablo 4: Turistlerin Yemek Öncelikleri}

\begin{tabular}{|c|c|c|c|}
\hline Kategoriler & Kodlar & $\mathrm{n}$ & Katılımcı \\
\hline \multirow{3}{*}{$\begin{array}{l}\text { Bölgeye Gelen Turistlerin Ye- } \\
\text { mek Öncelikleri }\end{array}$} & $\begin{array}{l}\text { Direk Çerkez yemekleri yemek için geli- } \\
\text { yorlar }\end{array}$ & 7 & $\begin{array}{l}\mathrm{K} 1, \mathrm{~K} 2, \mathrm{~K} 3, \mathrm{~K} 4, \mathrm{~K} 8, \\
\mathrm{~K} 10, \mathrm{~K} 12\end{array}$ \\
\hline & Kaliteli Hizmet ve Ürün Sunuyoruz & 1 & $\mathrm{~K} 2$ \\
\hline & Bölgeye Geldikten Sonra Karar Veriyorlar & 6 & $\begin{array}{l}\text { K5, K6, K7, K8, K9, } \\
\text { K11 }\end{array}$ \\
\hline \multirow{6}{*}{$\begin{array}{l}\text { Diğer Restoranlara Göre Ko- } \\
\text { num }\end{array}$} & Kültüre Dayalı Çalışıyoruz??? & 2 & $\mathrm{~K} 1, \mathrm{~K} 4$ \\
\hline & $\begin{array}{l}\text { Diğer Mutfaklara da Yer Verdiğimiz İçin } \\
\text { Avantajlıyız }\end{array}$ & 2 & $\mathrm{~K} 3, \mathrm{~K} 11$ \\
\hline & $\begin{array}{l}\text { Merkezde olduğunuzdan Dolayı Avantaj- } \\
\text { lıyız }\end{array}$ & 1 & K6 \\
\hline & $\begin{array}{l}\text { Bölgede Başka Çerkez Restorantı yok, Al- } \\
\text { ternatif Yok }\end{array}$ & 3 & K5, K9, K11 \\
\hline & $\begin{array}{l}\text { Sadece Kalhvaltı sunulduğu için } \\
\text { öncelikliyiz }\end{array}$ & 1 & K7 \\
\hline & Bölgede ilk olmanın avantajı & 2 & $\mathrm{~K} 8, \mathrm{~K} 12$ \\
\hline
\end{tabular}

Tablo 4'de Turistlerin yemek önceliklerini öğrenmek adına iki kategori halinde dördüncü soru yöneltilmiştir. İlk kategoride bölgeye gelen turistlerin yemek öncelikleri sorulmuştur. Katılımcılardan yedisi direk Çerkez yemeklerini tatmak için turistlerin geldiğini söylerken, 6 katılımcı ise bölgeye geldikten sonra Çerkez restorantında yemeye karar verdiklerini dile getirmiştir. Bu bağlamda K1 şu şekilde cevap vermiştir; "Bize gelenler ne yiyebiliriz diye araştırıp, yöresel lezzet tercih ve merak edenlerdir gelmeden önce araştırma yapıp geldikleri için doğrudan çerkez yemeği yemek için bölgeyi tercih ediyorlar. Düzce'de yöresel yemek yapan yerler yok denecek kadar az bu bizim için bir avantaj. Biz kazanca bağlı değil kültüre dayalı çalışıyoruz." İkinci kategoride ise katılımcılara diğer restoranlara göre konumlarını nasıl gördükleri sorulmuştur. 3 katılımcı bölgede başka alternatifleri olmadıkları için ön planda olduklarını ifade etmişlerdir. 2 katılımcının katıldığı diğer kodlar ise, kültüre dayalı hizmet verdiklerinden, diğer mutfaklara yer verdiklerinde ve bölgede ilk olmanın avantajlarını kullandıklarından dolayı konumlarının diğer restoranlara göre iyi olduğunu belirtmişlerdir. Bu Bağlamda K11 görüşlerini "Bölgeye gelen Rus, Ukrayna, Kafkas, Moldovya turistleri özellikle Çerkes yemekleri tercih ediyorlar. Çünkü onların damak tadına yakın ve özledikleri lezzetler. Ayn zamanda menümüzde olmayan ama onların istediği yemekler olursada yapıyoruz. Zaten şiparişli çalışıyoruz. Mutlaka bir gün önce istedikleri yemeği belirtmeleri lazım çünkü hazırlaması uzun süren yemekler. Diğer restaurantlar onlara bu imkanı sunmuyor ve alternatifleri çok ama bizim alternatifimiz yok." şeklinde dile getirmiştir. 


\subsection{4. Çerkez Yemeklerinin Diğer Etnik Yemeklere Göre Öne Çıkan Özellikleri}

Çalışma gurubundaki katılımcılara "Çerkez yemeklerini diğer etnik yemeklere göre öne çıkaran özellikleri nelerdir?” temel sorusu yöneltilmiştir. Katılımcıların verdiği cevaplara ilişkin özel ve önemli görülen kısımlar çalışma gurubunda yer alan kişilerin ifadeleri ile aşağıda özetlenmektedir.

Tablo 5: Çerkez Yemeklerinin Diğer Etnik Yemeklere Göre Öne Çıkan Özellikleri

\begin{tabular}{lll}
\hline Kodlar & $\mathrm{n}$ & Katılımc1 \\
\hline Yöresel, kültürel olması & 5 & $\mathrm{~K} 1, \mathrm{~K} 3, \mathrm{~K} 4, \mathrm{~K} 9, \mathrm{~K} 11$ \\
Lezzetlerin geçmişten günümüze aynen gelmesi & 1 & $\mathrm{~K} 2$ \\
Özel konseptte sunulması (1-2gün süren yemekler var) & 3 & $\mathrm{~K} 3, \mathrm{~K} 8, \mathrm{~K} 9$ \\
Herkese hitap etmesi & 1 & $\mathrm{~K} 5$ \\
Organik (doğal) ürünlerin kullanılması & 5 & $\mathrm{~K} 6, \mathrm{~K} 7, \mathrm{~K} 8, \mathrm{~K} 10, \mathrm{~K} 11$ \\
Kapsamlı olması & 2 & $\mathrm{~K} 8, \mathrm{~K} 12$ \\
\hline
\end{tabular}

Tablo 5'de Çerkez yemeklerinin diğer etnik yemeklere göre öne çıkan özellikleri sorulmuştur. En çok öne çıkan cevap 5 katılımcı ile yemeklerde organik ürünlerin kullanılmasıdır. İkinci cevap ise yemeklerin yöresel, kültürel özellik taşımalarıdır. Bu bağlamda verilen cevaplara bakıldığında K8 "Çok kapsamlı olması, merak ediliyor olması. Doğal ürünler olması. Çok meşakatli olması her yemek için 2 - 2,5 saat gerekli. Yoğun çalışmak gerekiyor” şeklinde görüşlerini aktarmıştır. K9 ise görüşlerini şu şekilde bildirmiştir; "Çok emek isteyen yemekler. Herşeyiyle bir kültürü hissettirmesi”.

\subsection{5. Çerkez Mutfağı Konusunda Eğitim Alma Durumu}

Çalışma gurubundaki katılımcılara "Çerkez mutfağı hakkında özel bir eğitim aldınız mı?” temel sorusu yöneltilmiştir. Katılımcıların verdiği cevaplara ilişkin özel ve önemli görülen kısımlar çalışma gurubunda yer alan kişilerin ifadeleri ile aşağıda özetlenmektedir.

Tablo 6: Çerkez Mutfağı Konusunda Eğitim Alma Durumu

\begin{tabular}{lll}
\hline Kodlar & $\mathrm{n}$ & Katılımc1 \\
\hline Hayır & 10 & $\mathrm{~K} 1, \mathrm{~K} 2, \mathrm{~K} 3, \mathrm{~K} 4, \mathrm{~K} 6, \mathrm{~K} 7, \mathrm{~K} 8, \mathrm{~K} 9, \mathrm{~K} 11, \mathrm{~K} 12$ \\
Aileden, atalarımızdan öğrendik & 5 & $\mathrm{~K} 1, \mathrm{~K} 4, \mathrm{~K} 8, \mathrm{~K} 10, \mathrm{~K} 11$ \\
Kültürel & 2 & $\mathrm{~K} 3, \mathrm{~K} 5$ \\
Araştırarak öğrendim & 1 & $\mathrm{~K} 6$ \\
\hline
\end{tabular}

Tablo 6'da Çerkez mutfağı konusunda eğitim alınıp alınmama durumu sorulmuştur. Katılımcıların hepsi özel bir eğitim almadıklarından bahsetmiştir. Sadece 1 katılımcı araştırarak öğrendiğini "Hayır. Böyle Bir Eğitim Alanıda Zaten Yok. Mesela Ben Çerkez 
Değilim. Araştırmacı Gazeteciyim. Çerkezler Üzerine Yaptığım Bir Araştırma Da Yemeklere İlgi Duydum ve Zamanla Bu Kültürde Buldum Kendimi. Yemek Kitabı Bile Yazdım 160 Çeşit Yemeğin Yer Aldı̆̆ı Bir Kitap Yazdım” sözleri ile dile getirmiştir. K1 ise görüşünü «Hayır. Bu lezzetler ile büyüdük anne babalarımızdan öğrendik” şeklinde dile getirmiştir.

\subsubsection{Restoran Menülerinde Yer Alan ve En Çok Tercih Edilen Çerkez Yemekleri}

Çalışma gurubundaki katılımcılara "Çerkez mutfağına özgü hangi yemekleri menünüzde bulunduruyorsunuz? En çok tercih edilen yemekleriniz hangileri? Sunumlarınız hakkında neler söyleyebilirsiniz?” temel sorusu yöneltilmiştir. Katılımcıların verdiği cevaplara ilişkin özel ve önemli görülen kısımlar çalışma gurubunda yer alan kişilerin ifadeleri ile aşağıda özetlenmektedir.

Tablo 7: Restoran Menülerinde Yer Alan ve En Çok Tercih Edilen Çerkez Yemekleri

\begin{tabular}{|c|c|c|c|}
\hline Kategoriler & Kodlar & $\mathrm{n}$ & Katılımcı \\
\hline \multirow{17}{*}{ Menüde bulanan yemekler } & Çerkez tavuğu & 3 & $\mathrm{~K} 1, \mathrm{~K} 4, \mathrm{~K} 11$ \\
\hline & Haluj & 8 & K1, K2, K4, K6, K8, K9, K10, K12 \\
\hline & Abaza peyniri & 4 & K1, K4, K8 K10 \\
\hline & Velibah & 4 & K2, K4, K5, K6 \\
\hline & Abista & 5 & K2, K8, K10, K11, K12 \\
\hline & Akudurşaşa & 3 & $\mathrm{~K} 2, \mathrm{~K} 8, \mathrm{~K} 12$ \\
\hline & Aktisizbal & 4 & K2, K8, K10, K12 \\
\hline & Kahvaltılar & 3 & K2, K5, K7 \\
\hline & Ahulçapa & 4 & K2, K8, K10, K12 \\
\hline & Piccin & 2 & K4, K6 \\
\hline & Gılnış & 2 & K4, K6 \\
\hline & Psihalive & 2 & K4, K5 \\
\hline & Gırniş & 1 & K5 \\
\hline & Gubate & 1 & K5 \\
\hline & Helvane & 1 & K5 \\
\hline & Sizbal & 2 & K8, K12 \\
\hline & Açaç & 4 & K8, K10, K11, K12 \\
\hline \multirow{3}{*}{ En çok tercih edilenler } & Haluj & 5 & K1, K4, K6, K10, K12 \\
\hline & Velibah & 2 & $\mathrm{~K} 2, \mathrm{~K} 7$ \\
\hline & Abista & 2 & K10, K11 \\
\hline \multirow{5}{*}{ Yemek sunumları } & Doğal kültürü yaştıyoruz & 1 & K1 \\
\hline & Özel sunum bulunmuyor & 4 & K2, K5, K6, K7 \\
\hline & $\begin{array}{l}\text { Konsept olarak hazırlanıyor, tercihe } \\
\text { sunulmuyor }\end{array}$ & 1 & K3 \\
\hline & Cevizli süslemeler & 1 & K4 \\
\hline & $\begin{array}{l}\text { Abista üzerine çerkez peyniri ve isli } \\
\text { peyniri }\end{array}$ & 1 & K12 \\
\hline
\end{tabular}


Tablo 7'de restoran menülerinde yer alan ve en çok tercih edilen Çerkez yemekleri hakkında bilgi istenmiştir. Restoranlarda çok farklı Çerkez yemeklerinin olduğu sonucuna ulaşılmıştır. Sadece Haluj yapan bir restoran da vardır. Restoranların menülerinde genel olarak en çok Haluj, Abista, Abaza peyniri, Velibah, Aktisizbal, Ahulçapa ve Açaç bulunmaktadır.

Katılımcıların cevaplarından elde edilen verilere göre en çok Halujun tercih edildiği görülmektedir. Sonrasında Velibah ve Abista gelmektedir. Yemek sunumları konusunda çoğu restoranın özel bir sunum yapmadığı sonucuna ulaşılmıştır.

\subsubsection{Gastroturistlerin Tercih Ettiği Yemekler ve Restoran Önerileri}

Çalışma gurubundaki katılımcılara "Gastro turistlerin genel tercih ettikleri bir yemek var mı? Yoksa önerilerinizi mi dikkate alıyorlar?” temel sorusu yöneltilmiştir. Katılımcıların verdiği cevaplara ilişkin özel ve önemli görülen kısımlar çalışma gurubunda yer alan kişilerin ifadeleri ile aşağıda özetlenmektedir.

\section{Tablo 8: Gastroturistlerin Tercih Ettiği Yemekler ve Restoran Önerileri}

\begin{tabular}{lll}
\hline Kodlar & $\mathrm{n}$ & Katılımc1 \\
\hline İlk defa yiyenlere öneriyoruz, & 1 & $\mathrm{~K} 1, \mathrm{~K} 6$ \\
Önerileri dikkate alıyorlar & 3 & $\mathrm{~K} 2, \mathrm{~K} 4, \mathrm{~K} 10$ \\
Araştırıp gelenler kendi tercih ediyor & 2 & $\mathrm{~K} 1, \mathrm{~K} 6$ \\
Daha önceden tadanlar kendi tercih ediyor & 2 & $\mathrm{~K} 1, \mathrm{~K} 5$ \\
ARkadaş tavsiyesi üzerine gelinen yemekleri yiyorlar & 1 & $\mathrm{~K} 8$ \\
Restoranımızda seçenek durumu yok & 1 & $\mathrm{~K} 3$ \\
İlk defa gelenlere tadım yaptırıllyor & 3 & $\mathrm{~K} 5, \mathrm{~K} 9, \mathrm{~K} 12$ \\
Kahvaltı & 2 & $\mathrm{~K} 7, \mathrm{~K} 8$ \\
Sipariş üsulüs tercih ediliyor önceden hazırlanıyor & 1 & $\mathrm{~K} 11$ \\
\hline
\end{tabular}

Tablo 8'de gastroturistlerin tercih ettikleri yemekler ve restoranların yemek önerilerine ait bilgiler yer almaktadır. Elde edilen verilere göre genellikle gastroturistlerin önerileri dikkate aldıkları (3 katılımcı) görülmüştür. K4 durumu "Genellikle önerilerimizi dikkate alıyorlar” şeklinde özetlemiştir. Ayrıca ilk defa gelenlere de tadım yaptıran 3 restoranın olduğu saptanmıștır. Araștırıp gelenler ve daha önceden yiyenlerin ise kendilerinin tercih ettikleri (2'şer katılımcı) bildirilmiştir. K5 soruyla ilgili "İlk defa gelenlere tadım yaptırıyoruz. Beğendiğini tercih ediyorlar. Daha önce gelenlerin belli tercihleri oluyor" şeklinde cevap vermiştir.

\subsubsection{Yöresel Ürün Kullanımı ve Yöresel Ürünlerin Gastroturistlerin Tercihlerine Olan Etkileri}

Çalışma gurubundaki katılımcılara "Yemeklerinizde yöresel ürünler kullanıyor musunuz? Evet ise bunları (müşterilerinizin bilmesi adına) ön plana çıkartıyor musunuz? Menünüzdeki yöresel Çerkez yemeklerinin turist çektiğini düşünüyor musunuz?” temel sorusu 
yöneltilmiştir. Katılımcıların verdiği cevaplara ilişkin özel ve önemli görülen kısımlar çalışma gurubunda yer alan kişilerin ifadeleri ile aşağıda özetlenmektedir.

Tablo 9: Yöresel Ürün Kullanımı ve Yöresel Ürünlerin Gastroturistlerin Tercihlerine Olan Etkileri

\begin{tabular}{llll}
\hline Kategoriler & Kodlar & $\mathrm{n}$ & Katılımc1 \\
\hline & Evet, yöresel & 9 & $\mathrm{~K} 1, \mathrm{~K} 2, \mathrm{~K} 3, \mathrm{~K} 6$, \\
& & $\mathrm{K} 7, \mathrm{~K} 8, \mathrm{~K} 10, \mathrm{~K} 11$, \\
$\begin{array}{l}\text { Yöresel ürün kullanma } \\
\text { durumu }\end{array}$ & Genelde yöresel & 1 & $\mathrm{~K} 12$ \\
& Tüm ürünleri kendimiz yapıyor, yetiştiriyoruz & 1 & $\mathrm{~K} 4$ \\
& Hayır ama kaliteli ürün kullanılıyor & 2 & $\mathrm{~K} 8$ \\
\hline $\begin{array}{l}\text { Yöresel ürünlerin ön plana } \\
\text { çlkartılma durumu }\end{array}$ & Yöresel ürün oldukları belirtiliyor & 1 & $\mathrm{~K} 1$ \\
\hline $\begin{array}{l}\text { Yöresel Çerkez yemeklerinin } \\
\text { turist çekme durumu }\end{array}$ & $\begin{array}{l}\text { Yemeklerin hikayeleri anlatılıyor } \\
\text { farkında geliyorlar }\end{array}$ & 2 & $\mathrm{~K} 3, \mathrm{~K} 4$ \\
\hline
\end{tabular}

Tablo 9'da restoranların yöresel ürün kullanımları ve bu durumun gastroturistlerin tercihine olan etkilerine ilişkin bilgiler yer almaktadır. Restoranların büyük çoğunluğu (9 katılımcı) \% 100 yöresel ürün kullandıklarını bildirmiştir. 2 restoran ise yöresel ürün kullanmadıklarını ama kaliteli ürünler ile yemeklerin yapıldıklarını bildirmiştir. Son kategoriye cevap veren katılımciların hepsi restorana gelen gastroturistlerin yemeklerin yöresel ürünlerle yapıldıklarının farkında olduklarını belirtmişlerdir.

K8 yöresel ürün kullanımı ve yemeklerin turist çekme durumu ile ilgili şu şekilde bir bilgilendirme yapmıştır: "Evet tamamı yöresel hatta çeşitli otları bahçemizde bizzat kendimiz ekiyoruz. Büyütüyor ve kullanıyoruz. Aynı şekilde peyniri kendimiz yapıyoruz. Biz dışarıdan hiç birşey almıyoruz tüm ürünleri kendimiz yapıyoruz. Bunu gelen herkes duyuyor. Bilerek geliyorlar. Tavsiye üzerine geliyor".

\subsubsection{Müşteri Portföyü ve Gastronomi Turistlerinin Portföydeki Yerleri}

Çalışma gurubundaki katılımcılara "Müşteri portföyünüz daha çok kimlerden oluşmaktadır? Portföyünüzün arasında gastronomi turistlerini nasıl sıralayabilirsiniz?” temel sorusu yöneltilmiştir. Katılımcıların verdiği cevaplara ilişkin özel ve önemli görülen kısımlar çalışma gurubunda yer alan kişilerin ifadeleri ile aşağıda özetlenmektedir. 
Tablo 10: Müşteri Portföyü ve Gastronomi Turistlerinin Portföydeki Yerleri

\begin{tabular}{|c|c|c|c|}
\hline Kategoriler & Kodlar & $\mathrm{n}$ & Katılımc1 \\
\hline \multirow{15}{*}{ Müşteri Portföyü } & Sağlıklı yaşama dikkate edenler & 3 & $\mathrm{~K} 1, \mathrm{~K} 10, \mathrm{~K} 12$ \\
\hline & Eğitimki Kişiler & 1 & K1 \\
\hline & Akademisyenler & 3 & $\mathrm{~K} 1, \mathrm{~K} 4, \mathrm{~K} 6$ \\
\hline & Emekliler & 1 & $\mathrm{~K} 2$ \\
\hline & Orta yaş çalışanlar & 1 & $\mathrm{~K} 2$ \\
\hline & Herkesime hitap ediliyor & 4 & $\mathrm{~K} 3, \mathrm{~K} 7, \mathrm{~K} 8, \mathrm{~K} 9$ \\
\hline & Gazeteciler & 1 & K4 \\
\hline & Hekimler & 1 & K4 \\
\hline & Avukatlar & 1 & K4 \\
\hline & Aileler & 1 & K5 \\
\hline & İş Yemekleri & 2 & $\mathrm{~K} 4, \mathrm{~K} 5$ \\
\hline & Dernek lokali & 1 & K10 \\
\hline & Çerkezler & 1 & K6 \\
\hline & İç anadolu halkı & 1 & K6 \\
\hline & Rus turistler & 1 & K11 \\
\hline \multirow{5}{*}{$\begin{array}{l}\text { Gastronomi turistlerinin portföydeki } \\
\text { yerleri, turist arttırma çalışmaları }\end{array}$} & Özel bir çalışma yok & 1 & $\mathrm{~K} 2$ \\
\hline & Tadım çalışmaları & 1 & K4 \\
\hline & Memmun ayrılmalarını sağlayarak & 1 & K5 \\
\hline & Sosyal medya paylaşımları & 1 & K12 \\
\hline & Reklamla uğraşmıyoruz & 1 & K6 \\
\hline
\end{tabular}

Tablo 10'da görüşmeye katılan restoranların müşteri portföyleri ve gastronomi turistlerinin portföydeki yerleri, turist arttırma çalışmalarına ilişkin bilgiler yer almaktadır. Müşteri portföyü konusunda çok farklı sonuçlar alınmış olsa da her kesime hitap ediyoruz diyen 4 katılımcı varken, 3’er katılımcı ise akademisyenler ve sağlıklı yaşama dikkat edenlerin müşteri portföylerini oluşturduklarını bildirmişlerdir. Bu konuda K1 "Sağlıklı yaşama dikkat eden eğitimli kişiler. Mesleki olarak en çok akademisyen ağırlıyoruz. Bizim için tavsiye ile gelinmesi önemli” şeklinde cevap vermiştir. K6 ise ilgili soruya "Daha çok Çerkezler ve iç Anadolu halkı geliyor. Yerli turistler, Kayseri de akademisyenler, iş adamları. Biz kültür yaşatıyoruz. Reklam vb şeyler ile uğraşmıyoruz” şeklinde görüş bildirmiştir.

\subsubsection{Diğer Çerkez Restoranlarından Ayırt Edici Unsurlar}

Çalışma gurubundaki katılımcılara "Diğer Çerkez mutfağı temalı restoranlardan sizi ayırt eden unsurlar nelerdir?” temel sorusu yöneltilmiştir. Katılımcıların verdiği cevaplara ilişkin özel ve önemli görülen kısımlar çalışma gurubunda yer alan kişilerin ifadeleri ile aşağıda özetlenmektedir. 


\section{Tablo 11: Diğer Çerkez Restoranlarından Ayırt Edici Unsurlar}

\begin{tabular}{lll}
\hline Kodlar & $\mathrm{n}$ & Katılımc1 \\
\hline Bölgede başka restoran yok, kıyas yapamıyoruz & 3 & $\mathrm{~K} 1, \mathrm{~K} 9, \mathrm{~K} 11$ \\
Uygun fiyat & 2 & $\mathrm{~K} 2, \mathrm{~K} 6$ \\
Kültürü yaşatıyoruz & 1 & $\mathrm{~K} 3$ \\
Her gün açık değiliz, rezervasyona göre hizmet veriyoruz & 1 & $\mathrm{~K} 3$ \\
Bölgede ilk olmanın avantajı & 1 & $\mathrm{~K} 4$ \\
Çerkez yemekleri dışında seşeneklerimizin olması & 1 & $\mathrm{~K} 5$ \\
Kahvaltı odaklı olması & 1 & $\mathrm{~K} 7$ \\
Ürünleri kendimiz üretmemiz & 1 & $\mathrm{~K} 8$ \\
Dernek lokali olması & 1 & $\mathrm{~K} 10$ \\
Daha butik çalışmamız & 1 & $\mathrm{~K} 11$ \\
Kullanılan malzemeler & 1 & $\mathrm{~K} 12$ \\
\hline
\end{tabular}

Tablo 11'de katılımcılara diğer Çerkez restoranlarından sizi ayıran nedir sorusu yöneltilmiştir. Genel olarak ortak bir fikir bağlılığına varılamasa da benzer cevaplara ulaşılmıştır. 3 katılımcı bölgedebaşka restoranın olmadığından dolayıkıyasyapamadıklarını ve rekabetin olmadığını bildirmiştir. K1 bu konuda şu şekilde cevap vermiştir: "Düzce Merkezde Başka Çerkez Restorandı bulunmuyor. Kıyaslama yapamıyorum”. 2 katılımcı ise uygun fiyatları ile ön plana çıktıklarından bahsetmiştir.

\section{SONUÇ}

$\mathrm{Bu}$ araştırmada Çerkez mutfağı gastronomi turizmi bağlamında incelenmiştir. Araştırma kapsamında 6 farklı ilde yer alan 12 Çerkez restoran sahibi ile görüşme yapılmıştır. Katılımcılar Çerkez mutfağının gastronomi turizmine etki ettiğini dile getirmişlerdir. Turizme katkının ise çoğunlukla yerli turist tarafından olduğu aktarılmıştır. Turistlerin Çerkez yemeklerine karşı tutumlarının ise olumlu olduğunu, lezzetlerin beğenildiği belirtilmiştir. Çerkez yemeklerinin yerli turistin damak tadına hitap ettiğini, damak tatlarının benzer olduğunu aktarmışlardır. Müşterilerin dönüşlerine göre, lezzetlerin farklı olduğunu düşünenlerde vardır. Bu durumun yabancı turistlerden kaynaklı olduğu düşünülebilir. Çerkez mutfağı uzun yıllardır Türk kültüründe yer edindiğinden dolayı yerli turistlerin lezzet konusunda çok fazla farklılık yaşamamakta oldukları söylenebilir.

Katılımcı 7 farklı restoran sahibinin aktardıklarına göre, bölgeye gelen turistlerin büyük çoğunluğu direkt ya da dolaylı yoldan Çerkez yemeklerini tatmak için gelmektedirler. 6 farklı restoran sahibi ise turistlerin bölgeye geldikten sonra Çerkez yemeklerini tatmak istediklerini dile getirmektedir.

Diğer restoranlara göre konumları sorusunda çok net cevaplar ya da benzeşen cevaplar alınamamıştır. Bunun en büyük nedeni iste bölgede tek Çerkez yemeklerine hitap eden 
restoran olmalarından, rekabetin olmadığından dolayıdır. Alternatifin olmaması nedeni ile diğer restoranlara göre konumları konusunda istatiksel bağlamda önemli cevaplar alınamamıştır.

Çerkez yemeklerini öne çıkaran unsurların başında yöresel ve kültürel olması, aynı zamanda organik ürünlerden yapılıyor olmasının geldiği belirtilmiştir. Ayrıca bazı restoran sahipleri, Çerkez yemeklerinin çok özel olmalarından dolayı öne çıktığını belirtmektedir. Ön sipariş ile hazırlanan 1-2 gün süren yemeklerin olduğunu dile getirmişlerdir. $\mathrm{Bu}$ nedenle bazı restoranlar önceden sipariş alarak çalıştıklarını belirtmişlerdir.

Eğitim alma konusunda 11 katılımcı aile mesleği olduğunu dile getirmiştir. Bu nedenle özel bir eğitim almadıklarını kültürlerini babadan oğula aktardıklarını belirtmişlerdir. Sadece 1 katılımcı araştırarak Çerkez yemeklerini öğrendiğini ve restoran açtığını belirtmiştir. $\mathrm{Bu}$ bağlamda bir eğitimin de olmadığını dile getiren katılımcılar da vardır.

En çok tercih edilen Çerkez yemeklerinin, Haluj, Abista, Abaza peyniri, Velibah, Aktisizbal, Ahulçapa ve Açaç olduğu sonucuna ulaşılmıştır. Turistlerin en çok tercih ettiği Çerkez yemeği ise Halujdur. Bu bağlamda bazı restoranların da tek yemek (Sadece Haluj) konsepti ile çalıştığını da burada belirtmekte yarar vardır. Yemek sunumları konusunda genel görüş özel bir sunumun olmadığıdır. Bu bağlamda Çerkez yemeklerinin özel sunumlar ile renklendirilmesi turistlerin ilgisini çekeceğinden dolayı, restoranlarına olan ilgiyi arttırabilir. Gastronomi turizmine katkısı olabilir. Örneğin, gelen turistlerce Instagram ya da Facebook gibi sosyal mecralarda paylaşılan sunumlar dikkat çekecektir. Günümüzde özellikle Instagram yemek paylaşımları konusunda önemli bir mecra halindedir.

Gastroturistlerin genellikle yemek tercihlerini restoranlara bıraktı̆̆g sonucuna ulaşılmıştır. Bunun nedeni olarak Çerkez yemekleri hakkında çok fazla bilgi sahibi olmamaları olarak görülebilir. Bunun yanı sıra, araştırarak gelen ve daha önceden yiyenlerin ise kendi tercihlerinin olduğu da aktarılmıştır. Ya da arkadaş tavsiyesi ile gelen turistlerin aynı yemekleri istedikleri de belirtilmiştir. 3 restoran ise müşterilerine tadım yaptırdıklarını dile getirmiştir.

Yöresel ürün kullanımı konusunda 9 katılımcı hemfikir olmuştur. 2 katılımcı yöresel olmayan ama kaliteli ürünleri kullandıklarını belirtmiştir. 1 katılımcı ise Çerkez yemeklerinde kullanılan tüm ürünleri kendi tarla ve bahçelerinde yetiştirdiklerini dile getirmiştir.

Müşteri portföyü konusunda çok farklı görüşler yer almıştır. Genel bir portföy birliği olduğu söylenemez. Yine de en çok bahsedilenler arasında, akademisyenler ve sağlıklı yaşama dikkat edenler (3'er katılımc1) şeklinde cevap alınabilmiştir. 4 restoran sahibi ise her kesime hitap ettiklerini dile getirmiştir.

Gastroturistlerin portföydeki yerleri ve turist artırma konusunda özel bir çalışma yapan restoranın neredeyse olmadığı sonucuna ulaşılmıştır. 1 katılımcı sosyal medya çalışmaları 
yaptıklarını dile getirmiştir. Bu bağlamda diğer katılımcılarında gastronomi turizmini arttırmak adına sosyal medyayı yoğun bir şekilde kullanmaları önemlidir. Hem ucuz hem de direkt potansiyel hedefe yönelik paylaşımlar ile gastronomi turizmini arttırma imkanları vardır. Özel sunumlar ve konsept restoranlar tasarlayarak bunların üzerinden pazarlama faaliyetleri çok rahatlıkla yapabilirler. Günümüzde günübirlik uçak seyahatleri bilet fiyatlarının ucuz olması nedeni ile yapılmaya başlanmıştır. Özellikle Gaziantep bu konuda önemli bir yerdedir. Ankara İstanbul gibi büyük illerden günübirlik Gaziantep gezileri hem kültürel hem de yöresel lezzetleri tatmak adına yapılmaktadır. Bu nedenle Çerkez mutfağının da Türkiye'nin her yerinde gastro turist çekme imkanları vardır. Bulundukları ile ya da ilçeler ile ortak turist çekme faaliyetleri düzenlenebilir.

Bu çalışma sonucunda turizm sektörüne ve sonraki araştırmacılara çeşitli önerilerde bulunulmuştur;

-Gastronomi turizmi ve çerkez mutfağının gastronomi turizmi içindeki yeri konusunda farkındalık yaratmak ve halkı bilinçlendirmek gerekmektedir.

•Çerkez mutfağı hakkında etkili tanıtım kampanyaları düzenlenmelidir.

-Türkiye’de çerkez mutfağını konseptinde hizmet veren, çerkez kültürünün hakim olduğu bölgeleri kapsayacak gastronomi turizmine yönelik kapsamlı paket turlar düzenlemelidirler.

-Çerkez mutfağı temalı çeşitli etkinlikler ya da festivaller düzenlenmeli ve her yıl devamlılı̆̆ı sağlanmalıdır.

- Gastronomi turizmi geliştirmek adına çerkez restoran sahiplerine çeşitli eğitimler verilmeli.

-Çerkez restoran sahipleri daha çok gastro turiste hitap edebilmek için gerekli reklam çalışmaları yapmalı.

-Çerkez restoranları hem kültürlerini yaşatmalı hem de herkese hitap edecek hizmet, lezzet sunmalı. Böylelikle daha çok gastro turiste hitap edebilecekler ve kültürlerini tanitabileceklerdir.

-İşletme sahiplerinin kültür yaşatmanın yanı sıra doğru tanıtım, reklam, ve pazarlama stratejileri ile gastronomi turizmine yerli ve yabancı gastro turistler kazandırmalı.

İleride yapılacak araştırmalar için;

-Çerkez restoranı pazarına girmeyi düşünen girişimciler açısından ya da var olan restoranına şube açmayı düşünen restoran sahipleri açısından pazar araştırması üzerine çalışmalar yapılabilir. 
-Çerkez restoranlarının ürün çeşitlendirmeleri üzerine araştımalar yapılabilir.

-Çerkez mutfağı konseptinde hizmet veren restoranların menü planlaması üzerine bir araştırma yapılabilir.

- Bu araştırmada veriler çerkez restoran sahipleri ve müssterileri ile görüşülerek toplanmıştır. Daha sonra yapılacak araştırmalarda çerkez halkın yaşadığı bölgeler tespit edilerek, çerkez kültürüne sahip kişilere çeşitli sorular yöneltilebilir bununla birlikte çerkez mutfağı hakkında kapsamlı bilgilere ulaşılabilir. Farklı bir bakış açısı ile çerkezlerin yaşadığı bölgelerde yerel halk ile çerkezlerin mutfak kültürlerinin etkileşimleri ölçülebilir. 


\section{KAYNAKÇA}

Akgöl, Y. (2012). Gastronomi turizmi ve Türkiye'yi ziyaret eden yabancı turistlerin gastronomi deneyimlerinin değerlendirilmesi. Yayımlanmamış yüksek lisans tezi, Mersin Üniversitesi Sosyal Bilimler Enstitüsü.

Baral, S. (2015). Neurogastronomy 101: The science of taste perception. http://www.eater. com/2015/10/19/9553471/what-is-neurogastronomy adresinden 16 Mart 2018 tarihinde alınmıştır.

Bilgin, A. ve Samancı, Ö. (2008). Türk Mutfă̆ı. T.C Kültür ve Turizm Bakanlığı: Ankara.

Birdir, K., ve Akgöl, Y. (2015). Gastronomi turizmi ve Türkiye'yi ziyaret eden yabanc1 turistlerin gastronomi deneyimlerinin değerlendirilmesi. İşletme ve İktisat Çalışmaları Dergisi, 3 (2), 57-68.

Bucak, T. ve Arac1, Ü.E. (2013). Türkiyede Gastronomi Turizmi Üzerine Genel Bir Değerlendirme. Balıkesir Üniversitesi Sosyal Bilimler Enstitüsü Dergisi. 30(16), 203216.

Cook, R. A., Yale, L. J. and Marqua, J. J. (2000). Tourism: The Business of Travel. Prentice Hall

Çağlı, I. B. (2012). Türkiye’de Yerel Kültürün Turizm Odaklı Kalkınmadaki Rolü: Gastronomi Turizmi Örneği. Yüksek Lisans Tezi, İstanbul Teknik Üniversitesi Fen Bilimleri Enstitüsü. İstanbul.

Demir, C. (2011). Mutfak turizminin destinasyon pazarlamasındaki önemi. Yayımlanmamış Yüksek Lisans Tezi, Gazi Üniversitesi Eğitim Bilimleri Enstitüsü, Ankara.

Dilsiz, B. (2010). Türkiye’de Gastronomi ve Turizm (İstanbul Örneği). Yayınlanmamış Yüksek Lisans Tezi, İstanbul Üniversitesi Sosyal Bilimler Enstitüsü, İstanbul.

Eren, S. (2007). Türk Mutfağ 1 ve Haccp Sistemi; Mutfak Profesyonellerinin Haccp Bilgilerinin Ölçülmesi, I. Ulusal Gastronomi Sempozyumu, 10-11 Nisan, Antalya, Türkiye.

Gökdeniz, A., Erdem, B., Dinç, Y., Uğuz, S. Ç. (2015). Gastronomi turizmi: Ayvalık’ta yerel turistler üzerinde görgül bir araştırma. Journal of Tourism and Gastronomy Syudies, 14,29 .

Green, G.P. and Dougherty, M.L. (2008). LocalisingLinkagesForFoodandTourism: CulinaryTourism As A Community Development Strategy. CommunityDevelopment, 39 (3), Sf. 148-158.

Güneş, G., Ülker, H. İ. ve Karakoç, G. (2008). Sürdürülebilir Turizmde Yöresel Yemek Kültürünün Önemi, 2.Ulusal Gastronomi Sempozyumu Bildirisi, Alanya, 17-18 Nisan

Hacıoğlu, N. ve Avcıkurt, C. (2011). Turistik Ürün Çeşitlendirmesi. Ankara: Nobel Akademik Yayıncılık. 
Hacıoğlu, N., Girgin, K. G. ve Giritoğlu, İ. (2009). Yiyecek-İçecek İşletmelerinin Pazarlama Faaliyetlerinde Yöresel Mutfakların Kullanımı - Balıkesir Örneği. 3. Ulusal Gastronomi Sempozyumu Bildirisi, Alanya, 17-18 Nisan

Kurgun, H. ve Özşeker, D.B. (2016). Gastronomi ve Turizm. Ankara: Detay Yayıncılık.

Long, L. (2003). Culinary tourism. Lexington. ABD: The University Press Of Kentucky.

Şanlıer, N, (2005). Yerli ve yabancı turistlerin Türk mutfağı hakkındaki görüşleri. Gazi Eğitim Fakültesi Dergisi, Cilt 25, Sayı 1, 213-227

Tezcan, M. (2000). Türk Yemek Antropolojisi Yazıları. Ankara: Kültür Bakanlı̆̆ı Yayınları.

TÜRSAB (2015). Gastronomi Turizmi Raporu. Türkiye Seyehat Acenteleri Birliği Yayınları.

UNWTO. (1995). İnternational Tourism: A Global Perspective. USA: WTO Education Network.

Ünlü, D. ve D. Dönmez (2008), Mutfakta Yenilik: Moleküler Gastronomi, II. Ulusal Gastronomi Sempozyumu, 10-11 Nisan, Antalya, Türkiye.

Yıldırım, A. ve Şimşek, H. (2016). Sosyal bilimlerde nitel araştırma yöntemleri. Ankara: Seçkin.

Yılmaz, K. (2017). Çerkes Mutfak Kültürü. Ankara: Tunç Yayıncılık.

Yükte Hafif Gastronomi; Tanıtımda Ağır Basıyor, (Tuyed) Turizm Gazeteci ve Yazarları Derneği), Panel 29. www.tuyed.org.tr/contdetail.asp?id=44 adresinden 20 Şubat 2018 tarihinde alınmıştır. 